\title{
Heavy Metal Contamination in Green Leafy Vegetables Collected from Selected Market Sites of Piliyandala Area, Colombo District, Sri Lanka
}

\author{
Thilini Kananke ${ }^{1, *}$, Jagath Wansapala ${ }^{2}$, Anil Gunaratne ${ }^{3}$ \\ ${ }^{1}$ Department of Food Science and Technology, Faculty of Applied Sciences, Sabaragamuwa University of Sri Lanka, Belihuloya, Sri Lanka \\ ${ }^{2}$ Department of Food Science and Technology, Faculty of Applied Sciences, University of Sri Jayewardenepura, Gangodawila, \\ Nugegoda, Sri Lanka \\ ${ }^{3}$ Department of livestock Production, Faculty of Agriculture, Sabaragamuwa University of Sri Lanka, Belihuloya, Sri Lanka \\ *Corresponding author: thilini.kananke@yahoo.com
}

Received August 09, 2014; Revised September 12, 2014; Accepted September 15, 2014

\begin{abstract}
The content of nickel (Ni), cadmium (Cd), chromium (Cr), lead $(\mathrm{Pb})$ and copper $(\mathrm{Cu})$ in five different types of green leafy vegetables viz., "Kangkung" (Ipomoea aquatica), "Mukunuwenna" (Alternanthera sessilis), "Thampala" (Amaranthus viridis), "Nivithi" (Basella alba) and "Kohila" (Lasia spinosa) collected from four randomly selected urban and sub urban market sites in and around Piliyandala area of Colombo District, Sri Lanka, were measured using atomic absorption spectrometry. The results showed significant differences in elemental concentrations among the green leafy vegetables analyzed. The average concentrations of heavy metals detected in green leafy vegetables ranged from $0.71-15.89,0.07-0.97,0.18-5.05,0.18-1.59,7.05-18.44 \mathrm{mg} / \mathrm{kg}$ for Ni, Cd, Cr, $\mathrm{Pb}$ and $\mathrm{Cu}$ respectively, on dry matter basis. In addition, the mean concentrations of metals in the green leafy vegetables were found in the order of their abundance as $\mathrm{Cu}>\mathrm{Ni}>\mathrm{Cr}>\mathrm{Pb}>\mathrm{Cd}$. However, there were no significant differences $(p<0.05)$ between the heavy metal contents in combined green leafy vegetables collected from the four market sites. It was also found that the $\mathrm{Ni}, \mathrm{Cd}, \mathrm{Cr}$ and $\mathrm{Pb}$ levels exceeded the maximum permissible limits set by $\mathrm{FAO} / \mathrm{WHO}$ for human consumption.
\end{abstract}

Keywords: contamination, green leafy vegetables, heavy metals, markets, Sri Lanka

Cite This Article: Thilini Kananke, Jagath Wansapala, and Anil Gunaratne, "Heavy Metal Contamination in Green Leafy Vegetables Collected from Selected Market Sites of Piliyandala Area, Colombo District, Sri Lanka." American Journal of Food Science and Technology, vol. 2, no. 5 (2014): 139-144. doi: 10.12691/ajfst-2-5-1.

\section{Introduction}

Green leafy vegetables (GLV) are key component of the Sri Lankan diet. These vegetables are valuable sources of vitamins, minerals, dietary fiber and anti oxidants [1,2]. Recently, there is an increased trend of consumption of GLV, particularly among the urban community. However, both vital and lethal elements are present in GLV. They can absorb heavy metals through contaminated soil and irrigation water sources. Further GLV have the ability to absorb the metals deposited on plant surfaces exposed to the polluted environments [3]. Although certain heavy metals $(\mathrm{Cr}, \mathrm{Mn}, \mathrm{Ni}, \mathrm{Zn}, \mathrm{Cu}$, and $\mathrm{Fe}$ ) are essential components for various biological activities within the human body, elevated levels of them can cause numerous health consequences to mankind. In contrast, $\mathrm{Pb}, \mathrm{Cd}, \mathrm{Hg}$ and $\mathrm{As}$ are non essential, toxic elements which are associated with many chronic diseases in human being [43].

A number of studies have shown the heavy metal contaminations of fruits and vegetables collected from production sites of various countries [4-19], including Sri Lanka as well $[20,21,22]$. Although the local scientists implicit the gravity of heavy metal contamination of GLV on consumer health, still there's no evidence of any research conducted to assess the degree of heavy metal pollution of GLV sold in Sri Lankan market sites, unlike in other countries [23-38]. Reference [38], shows increased levels of heavy metals in leafy vegetables from selected markets in Guyana due to atmospheric deposition. Lately [32], reported the occurrence of heavy metal contamination in leafy vegetables sold in markets of Libreville, Gabon, is also due to the atmospheric deposition. Metal concentrations in four leafy vegetables sold in markets of Abraka, Delta State, Nigeria was investigated by [23], while [2] reported the concentrations of heavy metals in fruits and leafy vegetables sold in selected markets of Lagos in Nigeria.

Most GLV marketing sites in Colombo District of Sri Lanka are located by the roadsides, where environment is heavily polluted with heavy metal-laden exhaust. Rapid industrialization and urbanization have caused, increased traffic activities in and around the capital which subsequently contributed to substantial accumulations of heavy metals in roadside environments. In addition, wide range of small scale industries including textile, battery production, galvanizing, metal products, and cable coating 
industries; brick kilns; diesel generators; re-suspended road dust etc. have also contributed to the heavy metal accumulation in the environment. Consequently, these toxic metals can be deposited on the vegetable surfaces during their production, transport and marketing [2,3]. These GLV may also be contaminated from heavy metals while farmers wash them with polluted water before taking them to the markets. It is therefore anticipated that the most consumed green leafy vegetables marketed along the roadside open markets in highly urbanized areas of Colombo District in Sri Lanka is contaminated with heavy metals.

Further, due to the persistent nature and cumulative behavior of heavy metals they have the ability to concentrate through food chains and cause toxic effects to the human [3]. Hence, there is a need to analyze these food items to ensure that the levels of these trace elements comply with permissible limits specified by local and international requirements. This is particularly important for GLV, where only limited data on heavy metal contents of such highly consumed agricultural materials are available. Hence, the present study was designed with the aim of determining the concentrations of $\mathrm{Ni}, \mathrm{Cd}, \mathrm{Cr}, \mathrm{Pb}$ and $\mathrm{Cu}$ in five types of key green leafy vegetables collected randomly from four urban and suburban market sites located in and around Piliyandala Area, Colombo District, Sri Lanka.

\section{Material and Methods}

\subsection{Sample Collection}

GLV were purchased from four market sites viz. Piliyandala (market 1), Kesbewa (market 2), Bandaragama (market 3) and Kahathuduwa (market 4) located in and around Piliyandala area, Sri Lanka. Four markets were randomly selected giving priority to the markets situated in roadsides open environments with heavy traffic loads. Market Site 1 and 2 were selected from highly urbanized Piliyandala and Kesbewa areas, while the other two markets were selected from the suburban Bandaragama and Kahathuduwa areas. The GLV purchased were "Kangkung" (Ipomoea aquatica), "Mukunuwenna" (Alternanthera sessilis), "Thampala" (Amaranthus viridis), "Nivithi" (Basella alba) and "Kohila” (Lasia spinosa). GLV samples were collected in clean polyethylene bags and brought to the laboratory for analysis.

\subsection{Sample Preparation and Analysis}

\subsubsection{Pre-treatment}

GLV samples procured from market sites were washed thoroughly with running tap water as prevalent during normal cooking process, to remove soil, dirt and other airborne pollutants. The edible parts were chopped in to small pieces.

\subsubsection{Drying}

Test portions were dried in a drying oven, at $105^{\circ} \mathrm{C}$, until obtained constant weight then cooled to ambient temperature, crushed by means of a clean pestle and mortar to obtain homogenized samples. The ground samples were then stored at room temperature in airtight sealed polyethylene bags until required for analysis by Atomic Absorption Spectrometry (AAS) after dry ashing technique as described in AOAC 999.11 [39].

\subsection{Instrumentation}

Metal concentrations were determined on a Thermo scientific ICE 3000 Series Atomic Absorption Spectrometer (AAS) outfitted with a background correction. The result of each sample represents an average of three replicate readings. Calibration curves of absorbance versus concentrations were plotted for each heavy metal and the concentration of each metal was determined from the calibration plot by interpolation.

\subsection{Quality Assurance}

Appropriate safety measures and quality assurance procedures were followed to ensure the reliability of the test results. All the chemicals and reagents used were of analytical and trace-metal grades. Properly cleaned glassware and utensils and distilled water was used during the research. Samples were cautiously handled to minimize the cross-contaminations and reagent blank determinations were carried out to correct the instrument readings.

\subsection{Statistical Analysis}

Mean concentrations of heavy metals in GLV were analyzed using Excel computer package. One way analysis of variance (ANOVA) was used to determine significant difference $(\mathrm{p}<0.05)$ between groups using Minitab Version 17.

\section{Results and Discussion}

Table 1, indicates the $\mathrm{Ni}, \mathrm{Cd}, \mathrm{Cr}, \mathrm{Pb}$ and $\mathrm{Cu}$ concentrations of five GLV collected from four randomly selected roadside open markets in and around Piliyandala area.

The observed concentrations of $\mathrm{Ni}, \mathrm{Cd}, \mathrm{Cr}, \mathrm{Pb}$ and $\mathrm{Cu}$ in the GLV were compared with the recommended limits established by the FAO/WHO to ensure the safety and well being of the consumers [40,41].

According to the Table 1, the average concentrations of heavy metals detected in GLV collected from the four market sites ranged from $0.71-15.89 \mathrm{mg} / \mathrm{kg}$ for $\mathrm{Ni}, 0.07-$ $0.97 \mathrm{mg} / \mathrm{kg}$ for Cd, $0.18-5.05 \mathrm{mg} / \mathrm{kg}$ for Cr, $0.18-1.59$ $\mathrm{mg} / \mathrm{kg}$ for $\mathrm{Pb}$ and $7.05-18.44 \mathrm{mg} / \mathrm{kg}$ for $\mathrm{Cu}$, on dry matter basis. Results showed that the mean concentrations of heavy metals in the green leafy vegetables found in the order of their abundance as $\mathrm{Cu}>\mathrm{Ni}>\mathrm{Cr}>\mathrm{Pb}>\mathrm{Cd}$.

Even though, $\mathrm{Cu}, \mathrm{Ni}$ and $\mathrm{Cr}$ are considered as essential elements for various biological activities within the human body, elevated levels of these metals can affect negatively on consumer health. Apart from being an important biocatalyst in the body, copper is essential for body pigmentation, maintenance of the central nervous system, preventing anemia and it is associated with the functions of $\mathrm{Fe}$ and $\mathrm{Zn}$ in the body [42]. Most plants contain inadequate amounts of copper for normal growth and are regularly provided through the application of artificial or organic fertilizers [43]. Further, the copper toxicity can induce lipid peroxidation, iron deficiency and membrane 
destruction within the body. Chromium is also an important trace metal required to stabilize the blood glucose levels, which in turns reduce the occurrence of diabetes, by the efficient use of insulin. It aids the breakdown of lipids in the body and increases the HDL cholesterols in the body while reducing the LDL cholesterol. Ingestion of high doses of chromium can cause irregular heartbeat, stomach distress, itching and flushing in human. In addition chromium can cause ulceration, liver and kidney damage [42-47].

Table 1. Heavy metal concentrations of Green Leafy Vegetables collected from selected market sites

\begin{tabular}{|c|c|c|c|c|c|}
\hline Commodity & $\mathrm{Ni}$ & $\mathrm{Cd}$ & $\mathrm{Cr}$ & $\mathrm{Pb}$ & $\mathrm{Cu}$ \\
\hline & \multicolumn{5}{|c|}{ Market 1 - Piliyandala } \\
\hline Mukunuwenna & 2.09 & 0.90 & 5.05 & 0.31 & 14.38 \\
\hline Nivithi & 6.39 & 0.72 & 2.82 & 0.97 & 13.49 \\
\hline Thampala & 1.09 & 0.54 & 1.10 & 1.04 & 12.09 \\
\hline Kangkung & 15.27 & 0.10 & 0.65 & 0.28 & 9.84 \\
\hline \multirow[t]{2}{*}{ Kohila } & 15.89 & 0.97 & 1.34 & 1.37 & 18.44 \\
\hline & \multicolumn{5}{|c|}{ Market 2 - Kesbewa } \\
\hline Mukunuwenna & 6.76 & 0.37 & 0.94 & 0.22 & 16.03 \\
\hline Nivithi & 3.34 & 0.51 & 1.34 & 0.54 & 12.87 \\
\hline Thampala & 0.94 & 0.22 & 1.86 & 1.09 & 11.37 \\
\hline Kangkung & 0.98 & 0.19 & 0.28 & 0.45 & 10.57 \\
\hline \multirow[t]{2}{*}{ Kohila } & 11.32 & 0.43 & 1.12 & 1.07 & 16.12 \\
\hline & \multicolumn{5}{|c|}{ Market 3 - Bandaragama } \\
\hline Mukunuwenna & 0.79 & 0.07 & 2.72 & 0.18 & 16.25 \\
\hline Nivithi & 1.83 & 0.18 & 3.37 & 0.64 & 7.05 \\
\hline Thampala & 3.56 & 0.34 & 2.32 & 0.54 & 10.63 \\
\hline Kangkung & 1.53 & 0.09 & 0.18 & 0.39 & 13.65 \\
\hline \multirow[t]{2}{*}{ Kohila } & 3.81 & 0.78 & 0.28 & 1.07 & 12.87 \\
\hline & \multicolumn{5}{|c|}{ Market 4 - Kahathuduwa } \\
\hline Mukunuwenna & 1.72 & 0.08 & 0.33 & 1.32 & 12.64 \\
\hline Nivithi & 2.35 & 0.43 & 1.04 & 0.44 & 10.31 \\
\hline Thampala & 0.71 & 0.11 & 3.07 & 0.96 & 9.21 \\
\hline Kangkung & 2.21 & 0.09 & 1.38 & 0.27 & 10.34 \\
\hline Kohila & 2.45 & 0.24 & 4.66 & 1.59 & 14.13 \\
\hline Average & 4.25 & 0.37 & 1.79 & 0.74 & 12.61 \\
\hline Maximum & 15.89 & 0.97 & 5.05 & 1.59 & 18.44 \\
\hline Minimum & 0.71 & 0.07 & 0.18 & 0.18 & 7.05 \\
\hline WHO/FAO & ${ }^{\$_{4}}$ & 0.2 & 2.3 & 0.3 & 40 \\
\hline
\end{tabular}

*Values in bold-face are higher than the safe limits of WHO/FAO.

${ }^{\$}$ According to Food and Nutrition Board: Institute of Medicine, 2010.

On the other hand $\mathrm{Cd}$ and $\mathrm{Pb}$ are non-essential toxic elements which cause carcinogenic effects and teratogenic abnormalities in human, even at very low concentrations [48]. Reference [52] reported that, when $\mathrm{Pb}$ is absorbed from the soil by crops, it lefts mainly in the root area as it cannot effectively go through the endodermis of roots. Leaves, however, can absorb vast quantities of $\mathrm{Pb}$ from the atmosphere. Hence, GLV have the capability to accumulate $\mathrm{Pb}$ from the soil as well as from the atmosphere through their leaves. Lead has been reported as a severe cumulative body toxin which enters the body through food, air and water and cannot be eliminated by washing the vegetables $[17,31]$. The elevated levels of $\mathrm{Pb}$ in certain leafy vegetables may also occur due to contaminants in irrigation water, soil or industrial and vehicular emission as lead occurs in the fuel as antiknocking agents [31]. Phosphate fertilizers are the major source of soil contamination by trace metals, especially $\mathrm{Cd}$, as it is naturally found as an impurity in phosphate rocks $[48,49]$. Nevertheless, $\mathrm{Cd}$ is a nonessential element, in plants and animals. Accumulation of $\mathrm{Cd}$ in plants affects the nutrients uptake, obstruct the respiratory enzymes, carbohydrate metabolism, photosynthesis, alter the antioxidant metabolism, and reduce the crop productivity $[48,49]$. Within the human body, Cd irreversibly accumulates in the kidneys, liver and lungs [2]. The kidneys and liver synthesize a Cd-inducible protein (metallothionein) which protects the cells by firmly binding with the toxic $\mathrm{Cd}$ ion. However, long-term ingestion of $\mathrm{Cd}$ might cause prostate, renal and ovarian cancers [48]. It was found that the $\mathrm{Ni}, \mathrm{Cd}, \mathrm{Cr}$ and $\mathrm{Pb}$ levels of some GLV obtained from the selected markets exceeded the safe limits established by FAO/WHO for human consumption (Table 1), thereby causing potential health risks to the consumers.

Figure 1. reports the concentrations of heavy metals found in all the GLV collected from the four market sites. Based on the results, the average concentrations of heavy metals in the four markets can be ranked in the increasing order as $\mathrm{Cd}<\mathrm{Pb}<\mathrm{Cr}<\mathrm{Ni}<\mathrm{Cu}$ (Figure 1 ).

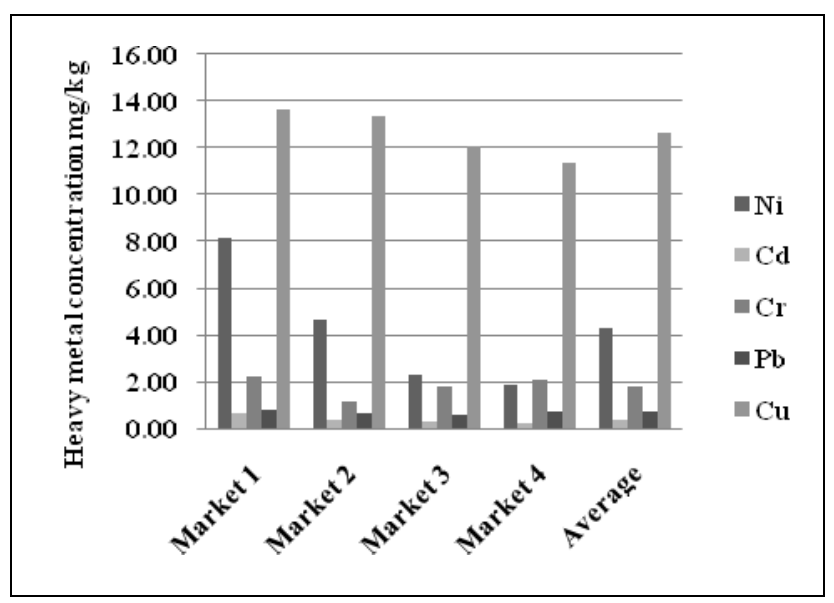

Figure 1. Mean concentrations of heavy metals of combined GLV from selected market sites

The highest concentrations of $\mathrm{Ni}, \mathrm{Cd}, \mathrm{Cr}, \mathrm{Pb}$ and $\mathrm{Cu}$ in the GLV were found in market 1, located at Piliyandala. The lowest concentrations of $\mathrm{Ni}, \mathrm{Cu}$ and $\mathrm{Cd}$ were found in the Kahathuduwa market, $\mathrm{Cr}$ in Kesbewa market and $\mathrm{Pb}$ in Bandaragama market.

The GLV collected from Piliyandala and Kesbewa markets reported the highest values for the analyzed heavy metals. With the rapid industrialization and urbanization in the above areas, the increment of traffic activities may contributes to the accumulations of heavy metals in roadside environments. $\mathrm{Cu}, \mathrm{Zn}, \mathrm{Cd}, \mathrm{Ni}, \mathrm{Cr}$ and $\mathrm{Pb}$ are the typical metal pollutants due to traffic activities. Emissions of heavy metals from vehicles include fuel combustion, road abrasion, lubricating oil, tire and break wear etc. Through the atmospheric deposit or road runoff, heavy metals can be absorbed into the plant tissues of GLV which are marketed along roadsides. However, there were no significant differences $(p>0.05)$ between the heavy metals found in combined GLV samples collected from the four market sites in Piliyandala area.

The present study was the first to analyze the heavy metals in GLV collected from market sites in Sri Lanka. However, several researches have shown that GLV cultivated in some parts of Colombo District, Sri Lanka are contaminated with heavy metals [21,22]. Reference [21] analyzed GLV, from Sedawatta, Welewatta, and Kotuwila in Wellampitiya Area, Colombo District, Sri 
Lanka and found high concentrations of $\mathrm{Cd}, \mathrm{Pb}, \mathrm{Zn}, \mathrm{Cu}$ and $\mathrm{Ni}$ which exceed the permissible limits set by FAO/ WHO. They have reported the average concentrations (mg kg-1 dry weight) of heavy metals in GLV as $0.59 \pm 0.44$ for $\mathrm{Cd}, 11 \pm 6$ for $\mathrm{Cu}, 13 \pm 9$ for $\mathrm{Ni}, 8 \pm 3$ for $\mathrm{Pb}$ and $40 \pm 20$ for $\mathrm{Zn}$. These values are higher than the mean values of $\mathrm{Cd}$, $\mathrm{Pb}, \mathrm{Ni}$ and $\mathrm{Cu}$ obtained for the GLV collected from the market sites of Piliyandala area during the current study.

There are many similar studies conducted in the other parts of the world to assess the heavy metal contamination of fruits and vegetables obtained from market sites. Shakya and Khwaounjoo [29] reported that the GLV collected from different market sites of Kathmandu Area in India, contains $\mathrm{Pb}$ and $\mathrm{Cd}$ levels higher than the maximum permissible limits set by FAO/WHO for human consumption and according to the findings average concentrations of all metals analyzed in GLV found in the order of $\mathrm{Zn}>\mathrm{Pb}>\mathrm{Cd}$. Ref. [30] shows that the levels of $\mathrm{Pb}$, $\mathrm{Cd}, \mathrm{Fe}, \mathrm{Cr}$ and $\mathrm{Cu}$ in four different samples of GLV purchased from Katsina Central Market contains levels of $\mathrm{Cu}, \mathrm{Zn}, \mathrm{Fe}$ and $\mathrm{Pb}$ below the WHO/FAO safety limits. The metals in the GLV have reported in the sequence of $\mathrm{Cu} \quad(0.483 \quad \mathrm{mg} / \mathrm{kg})>\mathrm{Zn} \quad(0.268 \quad \mathrm{mg} / \mathrm{kg})>\mathrm{Fe} \quad(0.260$ $\mathrm{mg} / \mathrm{kg})>\mathrm{Pb}(0.095 \mathrm{mg} / \mathrm{kg})>\mathrm{Cd}(\mathrm{ND})$. The mean values of $\mathrm{Pb}, \mathrm{Cd}$ and $\mathrm{Cu}$ reported in their study are lower than the values obtained in the present experiment. As in [2], the heavy metal levels of leafy vegetables collected from the selected markets in Lagos, Nigeria fall in the ranges (mg/kg) of $0.09 \pm 0.01$ to $0.21 \pm 0.06$ for $\mathrm{Pb} ; 0.03 \pm 0.01$ to $0.09 \pm 0.00$ for $\mathrm{Cd}$; $0.02 \pm 0.00$ to $0.07 \pm 0.00$ for $\mathrm{Cu}$ and $0.05 \pm 0.04$ to $0.24 \pm 0.01$ for Ni. Compared with the present study, these values are much lower. Ref. [31] analyzed the $\mathrm{Pb}$ concentrations of five randomly collected samples of leafy vegetables from two private markets in Metro Manila, Philippines and found that the most leafy vegetables are contaminated with $\mathrm{Pb}$. But, the concentrations were below the safe limits. However, the $\mathrm{Pb}$ content of the majority of GLV obtained from the four market sites during this study exceeded the safe limit established by WHO/FAO (Table 1). Reference [33] shows the $\mathrm{Pb}$ and $\mathrm{Cd}$ levels in vegetables obtained from four fresh markets in Surut Thani, Thailand. Even the $\mathrm{Pb}$ contents of the vegetables complied with the standard of the Ministry of Public Health, Thailand, the Cd was higher than the maximum allowable limits specified by the Australia-New Zealand, Codex, China and the European Union standards. Comparatively both $\mathrm{Pb}$ and $\mathrm{Cd}$ concentrations of some GLV obtained from the four markets exceeded the permissible limits of WHO/FAO in the present study. [1], has reported that the concentrations $(\mathrm{mg} / \mathrm{kg})$ of heavy metals in some Green Leafy Vegetables obtained from Sulaimani, KurdistanIraq, falls in the ranges of 6.118 to 339.646 for $\mathrm{Fe}, 0.041$ to 0.247 for $\mathrm{Cr}, 0.000$ to 0.027 for $\mathrm{Cd}, 0.196$ to 0.301 for $\mathrm{Cu}, 0.037$ to 0.503 for $\mathrm{Ni}$ and 0.690 to 2.016 for $\mathrm{Zn}$. These values are also much lower compared to the values of the present study (Table 1).

The results indicated that the average concentrations of heavy metals in five types of GLV selected have also increased in the order of $\mathrm{Cd}<\mathrm{Pb}<\mathrm{Cr}<\mathrm{Ni}<\mathrm{Cu}$ (Figure 2). Among the five types of GLV studied from the selected markets, highest capability of accumulating $\mathrm{Ni}, \mathrm{Cd}, \mathrm{Pb}$ and $\mathrm{Cu}$ were found in Kohila leaves, while the highest amount of $\mathrm{Cr}$ was found in Mukunuwenna (Figure 2). According to the results, the lowest levels of $\mathrm{Cd}$ and $\mathrm{Cr}$ were in Kangkung; $\mathrm{Ni}$ and $\mathrm{Cu}$ in Thampala; and $\mathrm{Pb}$ in Mukunuwenna. In the present study, significant differences were found in $\mathrm{Pb}(\mathrm{P}=0.006$, one-way ANOVA) and $\mathrm{Cu}$ ( $\mathrm{P}=0.011$, one-way ANOVA) concentrations between the test vegetables but not in $\mathrm{Ni}$, Cd and $\mathrm{Cr}$ concentrations. Market and field samples of amaranth and cabbage from Zanzibar, Tanzania have observed by [35] and found that the Amaranth has significantly higher concentrations of $\mathrm{Zn}, \mathrm{Fe}, \mathrm{Cr}$ and $\mathrm{Mn}$ than cabbage, while $\mathrm{Cd}, \mathrm{Ni}$ and $\mathrm{Pb}$ contents are significantly higher in cabbage than amaranth. Further, $\mathrm{Pb}$ and $\mathrm{Cd}$ concentrations were above the WHO/FAO tolerable limits. Ref. [38] analyzed the heavy metal levels in leafy vegetables from selected markets in Guyana. Leafy vegetables (Brassica oleracea, Brassica chinensis, Basella alba, and Lactuca sativa) from market sites were tested for $\mathrm{Cd}, \mathrm{Pb}, \mathrm{Cu}, \mathrm{Zn}, \mathrm{Co}, \mathrm{Ni}, \mathrm{Mn}$, and $\mathrm{Fe}$. Results indicate significant differences in elemental concentrations among the vegetables analyzed, with $\mathrm{Cd}$, $\mathrm{Co}$, and $\mathrm{Mn}$ exceeding the safe limits in all vegetables, and $\mathrm{Pb}$ and $\mathrm{Fe}$ exceeding this limit in some vegetables. $\mathrm{Cu}$ and $\mathrm{Zn}$ levels maintained within the safe limits in all of the vegetables. In the present study also the $\mathrm{Cu}$ levels did not exceeded in any of the GLV analyzed.

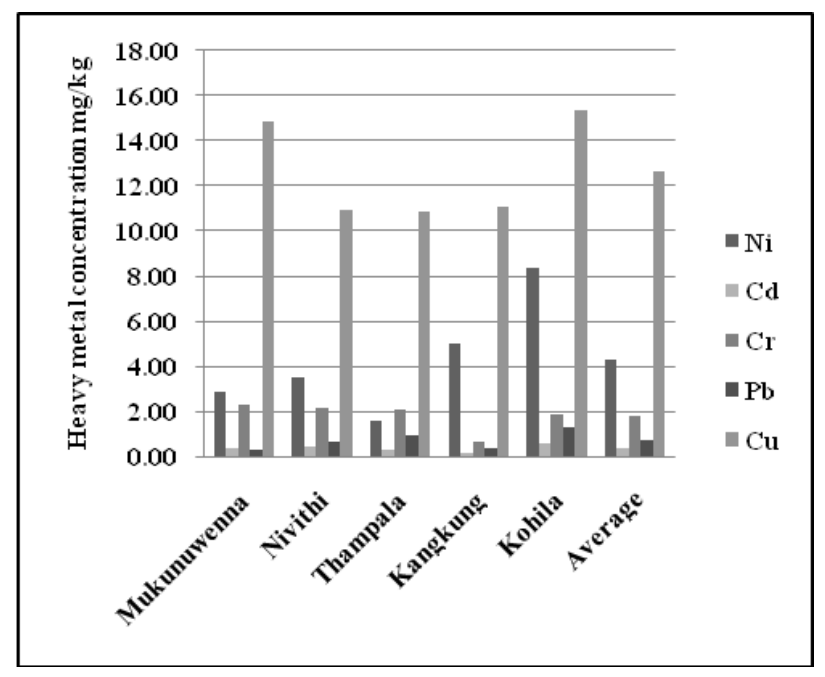

Figure 2. Mean concentrations of heavy metals of selected Green Leafy Vegetables from combined market sites

According to the preliminary survey conducted the GLV sold in the selected market sites were mainly collected from the fields located in and around Piliyandala area (Polgasowita, Bandaragama, Kahathuduwa). The elevated levels of heavy metals found in GLV might be closely related to the contaminated soils and irrigation water, fertilizer and pesticides or due to the atmospheric deposition of metals on plant surfaces during their production, transportation and marketing [50]. Uptake of heavy metals by crops is often affected upon the plant species, growth phase, type of the soil and metal species, soil condition, weather and environment [51,52,53]. Moreover, the atmospheric depositions and marketing systems of vegetables play a significant role in elevating the levels of heavy metals in GLV causing potential health hazards to the consumers $[12,43,44,45,46,47]$.

\section{Conclusion}

From the present study it can be concluded that Ni, Cd, $\mathrm{Cr}$ and $\mathrm{Pb}$ concentrations in some green leafy vegetables 
obtained from the selected markets were above the permissible limits set by FAO/WHO for human consumption. However, the levels of $\mathrm{Cu}$ in all the GLV collected found below the maximum permissible limit. Long term consumption of heavy metal contaminated GLV may possibly cause numerous health hazards in human. Therefore, regular monitoring of heavy metals in GLV is crucial to avoid excessive buildup of these metals in the human food chain.

\section{Acknowledgement}

The authors gratefully acknowledge University Grants Commission, Sri Lanka, for their financial support to conduct the study.

\section{References}

[1] Abdulazeeza Z.M., and Azizb J.M.A., "Study of heavy metals in some Green Leafy Vegetables in Sulaimani, Kurdistan-Iraq”. Int. J. of Multidisciplinary and Current research, May/June 2014.

[2] Sobukola O.P., Adeniran O.M., Odedairo A.A., Kajihausa O.E., "Heavy metal levels of some fruits and leafy vegetables from selected markets in Lagos, Nigeria”. Afr. J. Food Sci., 4(2). 389393. 2010.

[3] Sharma, R.K., Agrawal, M. and Marshall, F.M., "Heavy metals in vegetables collected from production and market sites of a tropical urban area of India”. Food and Chemical Toxicology, 47. 583-591. 2009.

[4] Hu X., Jin W., Luv W., Cheng S. and Jiang Y., "Investigation and Evaluation on Heavy Metal Copper and Cadmium Contaminations of Vegetables Grown in Huanggang City of China”. Advance Journal of Food Science and Technology, 5(2). 106-109. 2013.

[5] Su S., Tsui C., Lai H. and Sang Z., "Food Safety and Bioavailability Evaluations of Four Vegetables Grown in the Highly Arsenic-Contaminated Soils on the Guandu Plain of Northern Taiwan”. Chen. Int. J. Environ. Res. Public Health, 11. 4091-4107. 2014.

[6] Parvin R., Sultana A., Zahid A., "Detection of Heavy Metals in Vegetables Cultivated In Different Locations in Chittagong, Bangladesh”. IOSR Journal of Environmental Science, Toxicology and Food Technology (IOSR-JESTFT), 8(4). 58-63. 2014.

[7] Olufunmilayo O.O., Oludare A.H. and Oluwatoyin D., "Determination of Concentrations of Heavy Metals in Municipal Dumpsite Soil and Plants at Oke-ogi, Iree, Nigeria”. International Research Journal of Pure \& Applied Chemistry, 4(6). 656-669, 2014.

[8] Ekpo, F. E., Ukpong, E. J. and Udoumoh, I. D. J., "Bioaccumulations of Heavy Metals on Soil and Arable Crops Grown in Abandoned Peacock Paint Industry in Ikot Ekan, Etinan Local Government Area, Akwa Ibom State, Nigeria”. Universal Journal of Environmental Research and Technology. 4(1). 39-45. 2014.

[9] Ondo J.A., Prudent P., Massiani C., Höhener P., and Renault P., "Effects of agricultural practices on properties and metal content in urban garden soils in a tropical metropolitan area”. J. Serb. Chem. Soc., 79 (1). 101-112. 2014.

[10] Ihesinachi K. and Eresiya D., "Evaluation of heavy metals in orange, pineapple, avocado pear and pawpaw from a farm in Kaani, Bori, Rivers State Nigeria”. International Research Journal of Public and Environmental Health, 1 (4). 87-94. June 2014

[11] Kalagbor I.A., Barisere V., Barivule G., Barile S. and Bassey C., "Investigation of the Presence of Some Heavy Metals in Four Edible Vegetables, Bitter Leaf (Vernonia amygdalina), Scent Leaf (Ocimum gratissimum), Water Leaf (Talinum triangulare) and Fluted Pumpkin (Telfairia occidentalis) from a Cottage Farm in Port Harcourt”. Research Journal of Environmental and Earth Sciences, 6(1). 18-24, 2014.

[12] Osundiya M. O., Ayejuyo O. O., Olowu R. A., Bamgboye O. A. and Ogunlola A. O., "Bioaccumulation of heavy metals in frequently consumed leafy vegetable grown along Nigeria-Benin Seme Border, West Africa”. Adv. Appl. Sci. Res., 5(1). 1-7. 2014.

[13] Pauline L., Säumel I., "Orchards for edible cities: Cadmium and lead content in nuts, berries, pome and stone fruits harvested within the inner city neighbourhoods in Berlin, Germany". Ecotoxicology and Environmental Safety, 101.233-239. 2014.

[14] Kulkarni D.K., Delbari A.S. and Mahajan D.M., "Bio concentration factor (BCF) for heavy metals detection and selection of hyper-accumulator plants. Case study of Pune-India and Tehran -Iran”. Indian Journal of Fundamental and Applied Life Sciences, 4(1). 163-170. 2014.

[15] Chang Y., Yu H. Y., Chen J. J., Li F. B., Zhang H. H. and Liu C. P., "Accumulation of heavy metals in leaf vegetables from agricultural soils and associated potential health risks in the Pearl River Delta, South China”. Environ Monit Assess., 186. 15471560. 2014.

[16] Ramesh, H. L. and Yogananda Murthy, V. N., "Assessment of Heavy Metal Contamination in Green Leafy Vegetables Grown in Bangalore Urban District of Karnataka”. Advances in Life Science and Technology, 6. 2012.

[17] Abbas M., Parveen Z., Iqbal M., Riazuddin, Iqbal S., Ahmed M. and Bhutto R., "Monitoring of toxic metals (Cadmium, Lead, Arsenic and Mercury) in vegetables of Sindh, Pakistan". Kathmandu University Journal of Science, Engineering and Technology, 6(II). 60-65. 2010.

[18] Asdeo A. and Loonker S., "A Comparative Analysis of Trace Metals in Vegetables". Research Journal of Environmental Toxicology, 5. 125-132. 2011.

[19] Gupta, S., Jena, V., Jena, S., Davic, N., Matic, N., Radojevic, D. and Solanki, J. S., "Assessment of heavy metal contents of green leafy vegetables”. Croat. J. Food Sci. Technol., 5 (2). 53-60. 2013.

[20] Jayasinghe B.S., Jayawardena M.I.F.P. and Pathiratne K.A.S., "Comparison of Chromium levels of Water Spinach samples with those of field water samples". Proceedings of the $9^{\text {th }}$ International Conference on Environmental Science and Technology, Rhodes Island, Greece. 2005.

[21] Premarathna H.M.P.L., Indraratne S.P. and Hettiarachchi G., "Heavy metal concentration in crops and soils collected from intensively cultivated areas of Sri Lanka”. 19th World Congress of Soil Science. 2010.

[22] Rathnayaka R.M.P.S., Premarathna H.M.P.L. and Ariyaratne G.M.H., "Heavy metal accumulation by some selected leafy vegetables grown in Wellampitiya area". Proceedings of the Peradeniya University Research. 2004.

[23] Agbogidi, O.M. and Erhenhi, H. A., "Metal Concentrations in Four Leafy Vegetables Sold in Markets of Abraka, Delta State, Nigeria”. J. Biol. Chem. Research, 30 (2). 813-822. 2013.

[24] Doherty V. F., Sogbanmu T. O., Kanife U. C. and Wright O., "Heavy metals in vegetables collected from selected farm and market sites in Lagos, Nigeria”. Global Advanced Research Journal of Environmental Science and Toxicology, 1(6). 137-142, September, 2012.

[25] Elbagermi, M.A., Edwards, H.G.M., Alajtal, A.I., "Monitoring of heavy metal content in fruits and vegetables collected from population and market sites in the Misurata area of Libya”. Intl. Scholarly Res. Network, 10. 1-5. 2012.

[26] Ladipo, M.K. and Doherty, V.F., "Heavy metal levels in vegetables from selected Markets in Lagos, Nigeria”. Afr. J. Food Sci. Technol., 2(1). 18-21. 2011.

[27] Mohamed H.H. Ali, Khairia M. Al-Qahtani, "Assessment of some heavy metals in vegetables, cereals and fruits in Saudi Arabian markets”. The Egyptian journal of Aquatic Research, 38(1). 31-37. 2012.

[28] Nogaim, Q.A., Makarem, M., Alwah, M. and Atef, M., "Survey of some heavy metals in Yemeni vegetables". Merit Research Journal of Food Science and Technology, 1(3). 36-42. December, 2013

[29] Shakya, P.R. and Khwaounjoo, N.M., "Heavy Metal Contamination in Green Leafy Vegetables Collected From Different Market Sites Of Kathmandu And Their Associated Health Risks". Scientific World, 11 (11). July 2013.

[30] Shuaibu L. K., Yahaya M., and Abdullahi U. K., "Heavy metal levels in selected green leafy vegetables obtained from Katsina central market, Katsina, Northwestern Nigeria”. African Journal of Pure and Applied Chemistry, 7(5). 179-183. May, 2013.

[31] Zamor, P.W., Jesu, J.D., Sia, G., Ragragio, E., Su, M.L.S. and Villanueva, S., "Assessing Lead Concentrations In Leafy Vegetables In Selected Private Markets In Metro Manila, 
Philippines”. Journal of Applied Technology in Environmental Sanitation,. 2 (3). 175-178. 2012.

[32] Mebale A.A., Ndong R.O., Affane A.L.N., Omanda H.M., Nziengui P.P., Biyogo R.M., Ondo J.A., "Assessment of Metal Content in Leafy Vegetables Sold in Markets of Libreville, Gabon”. Int J Cur Res Rev, 06 (01). 28-33. 2014.

[33] Nipaporn M., Nattapan S. and Rattana W., "Analysis of Lead and Cadmium Contents in Local Vegetables in Surat Thani, Thailand". Walailak J Sci \& Tech., 11(6). 455-461. 2014.

[34] Agbogidi, O.M., "Trace metal profile of some fruits in Kokori and Abraka Market, Delta State, Nigeria”. International Journal of Scholarly Research Gate, 2(1). 2014.

[35] Mohammed N. K., Khamis F. O., "Assessment of heavy metal contamination in vegetables consumed in Zanzibars". Natural Science, 4. 588-594. 2012.

[36] Elbagermi M. A., Edwards H. G. M., and Alajtal A. I., "Monitoring of HeavyMetal Content in Fruits and Vegetables Collected from Production and Market Sites in the Misurata Area of Libya”. ISRN Analytical Chemistry. Article ID 827645. 2012.

[37] Ghosh R., Xalxo R. and Ghosh M., "Estimation of Heavy Metal in Vegetables from Different Market Sites of Tribal Based Ranchi City through ICP-OES and to Assess Health Risk”.Curr. World Environ. 8(3). 435-444. 2013.

[38] Nankishore A., "Heavy metal levels in leafy vegetables from selected markets in Guyana”. Journal of Agricultural Technology, 10(3): 651-663. 2014.

[39] Official Methods of Analysis. 15th Ed., AOAC, Arlington, VA, Method 999.11. 2002.

[40] FAO/WHO. Joint Expert Committee on Food Additives, "Summary and Conclusions", in Proceedings of the 53rd Meeting of Joint FAO/WHO Expert Committee on Food Additives, Rome, Italy. 1999.

[41] FAO/WHO, Codex Alimentarius Commission. Food Additives and Contaminants. Joint FAO/WHO Food Standards programme, ALINORM 01/12A:1-289. 2001.

[42] Jarup L., "Hazards of heavy metals contamination". Br. Med. Bull., 68. 167-182. 2003
[43] Chen Y., Wu P., Shao Y., Ying Y., "Health risk assessment of heavy metals in vegetables grown around battery production area". Sci. Agric., 71(2).126-132, March/April 2014.

[44] Mollazadeh N., "Metals health risk assessment via consumption of vegetables”. Intl J Agri Crop Sci., 7 (8). 433-436. 2014.

[45] Sardar K., Ali S., Hameed S., Afzal S., Fatima S., Shakoor M.B., Bharwana S.A., Tauqeer H.M., "Heavy Metals Contamination and what are the Impacts on Living Organisms. Greener Journal of Environmental Management and Public Safety ISSN: 2354-2276 Vol. 2 (4), pp. 172-179, August 2013.

[46] Guerra F., Trevizam A.R., Muraoka T., Marcante N.C., Brazaca S.G., "Heavy metals in vegetables and potential risk for human health”. Sci. Agric., 69 (1). 54-60. January/February 2012.

[47] Kaur H. and Goyal D., "Assessing potential risk of heavy metal exposure in green leafy vegetables". International Journal of Research in Environmental Science and Technology, 1(4).43-46. 2011.

[48] Nazar, R., Iqbal, N., Masood, A., Iqbal, M., Khan, R., Syeed, S. and Khan, N., "Cadmium toxicity in plants and role of mineral nutrients in its alleviation”. American Journal of Plant Sciences 3:1476-1489. 2012

[49] Bakhshayesh B.E., Delkash M., and Scholz M., "Response of Vegetables to Cadmium-Enriched Soil”. Water, 6. 1246-1256. 2014.

[50] Mashi A., El-Ladan I.Y. and Yaro A., "Atmospheric contamination by heavy metals in Ilupeju industrial area of Lagos". S Int.J.Curr.Microbiol.App.Sci., 3(2): 833-840. 2014.

[51] Richards, B., Steenhus, T., Peverly, J. and McBride, M., "Effect of sludge-processing mode, soil texture and soil $\mathrm{pH}$ on metal mobility in undisturbed soil columns under accelerated loading”. In: Environmental Pollution 109: 327-346. 2000.

[52] Domergue, F.L. and Vedy, J.C., "Mobility of heavy metals in soil profiles”. Int. Environ. Chem. 46: 13-23. 1992.

[53] Chang, A.C., Page, A.L., Foster, K.W. and Jones, T.E., “A comparison of cadmium and zinc accumulation by four cultivars of barley grown in sludge-amended soils". J. Environ. Qual. 11 (3) 526-654. 1984. 